\title{
Engineering the global ecosystem
}

\author{
William T. Stringfellow $\cdot$ Ravi Jain
}

Published online: 29 May 2010

(c) The Author(s) 2010. This article is published with open access at Springerlink.com

We thrive and survive on planet Earth as a single human family. And one of our main responsibilities is to leave successor generations a sustainable Former UN Secretary General Kofi Annan

\section{Introduction}

In 1952, Isaac Asimov wrote a vivid tale about human explorers engineering the ecosystem of Mars to make it habitable for humans (Asimov 1952). In science fiction, engineers use terraforming machines to modify the atmosphere, landscape, and hydrology of Mars to create ecosystems that sustain earth-based life-forms. Since that time, rapid advances in population density, combined with ideas concerning engineering and finance, have allowed us to recreate the ecosystem of our home planet. However, our Earth-based "terraforming" efforts have not sufficiently included ecosystem function in our engineering designs and, as a result, a number of negative consequences are occurring.

Engineering has had a great history of achievement in designing and building hydrologic structures and actualiz-

W. T. Stringfellow $(\bowtie) \cdot$ R. Jain

Ecological Engineering Research Program, School

of Engineering and Computer Science, University of the Pacific,

3601 Pacific Avenue, Stockton, CA 95211, USA

e-mail: wstringfellow@pacific.edu

W. T. Stringfellow

Geochemistry Department, Lawrence Berkeley National

Laboratory, Berkeley, CA 94720, USA ing fantastic ideas, such as the Roman aqueducts, the canals of Angkor Wat, or the Bhakra Nangal dam. Engineering over the ages has transitioned from a focus on structural greatness to engineering the manipulation of natural cycles and systems, including the hydrologic cycle. These designs and manipulations typically regard only the immediate application (e.g., flood control, water supply), not the needs of the regional and global ecosystem, and therefore impart unintended consequences as a result of this oversight.

In the last 50 years, the world population has more than doubled, from less than 3 billion people to an estimated 6.8 billion people today (United States Census Bureau 2010). Current projections are for the world population to reach nine billion within the next generation. Despite the potential for disaster, arguably the human condition has improved as population density increased. The Human Development Index (HDI), a measurement that incorporates life expectancy, access to education, and standard of living, has risen for all of the $82 \mathrm{UN}$ member states for which there is comparative data between 1980 and 2007 (United Nations Development Programs, 2009). The average increase for states ranked as having low development (scores less than 0.50) in 1980 was almost $140 \%$, with ten out of 21 states moving from the low development to medium development categories. The HDI also increased in countries ranked in 1980 as medium development $(120 \%)$ and high or very high development $(110 \%$ of the 1980 values). Other measurements of the human condition, such as access to drinking water, undernourishment, and poverty rates, show trends that indicate the human condition is improving (United Nations 2008; United Nations Environmental Programs 2010). The human condition has been uplifted in large part due to engineering that has transformed our landscape and hydrology on a local, regional, and global scale. 


\section{Engineering agricultural ecosystems}

The post-war success in feeding and improving the lives of the growing population has come as a result of humans deliberately engineering agricultural landscapes. Expansion of arable agricultural lands has occurred by engineering the removal of wetlands, via drainage systems, levees, and other structures (Foote et al. 1996; Lemly et al. 2000; Huang et al. 2010). The removal of wetlands has negative impacts on ecosystem services (i.e., economically quantifiable ecosystem benefits, such as recharge of drinking water aquifers, support of fisheries, recreational opportunities, etc.). Among the many benefits of wetlands are the removal of dissolved nitrogen from polluted waters and the provision of flood control (Der 1999; Nicholls et al. 1999; Zedler and Callaway 2000; Nicholls 2004; Zedler and Kercher 2005; Blann et al. 2009; Doyle and Yates 2010; Stringfellow et al. 2010; Wamsley et al. 2010).

While countries such as Brazil and China have used rapid expansion of agricultural lands to improve agricultural production (62 and 65\% improvement in productivity between 1961 and 2006), other counties, including India, France, and the United States, have increased agricultural production without expanding agricultural lands (Fig. 1). India and the United States increased total production by 35 and $21 \%$, respectively. France, which has deliberately resisted adoption of many modern farming methods, had a small increased in specific production, but not total production, and had a 9\% decrease in land under agricultural use. After 1990, the amount of global land actively in agricultural use has not increased greatly (Fig. 2), but agricultural production has kept pace with an estimated $20 \%$ increase in population (United Nations 2008; United States Census Bureau 2010).

\section{Engineering regional hydrologic cycles}

Increased agricultural production has been supported by many factors, including the well-documented utilization of improved variants and agricultural chemicals, the so-called "Green Revolution" (United Nations 2008). A less widely recognized factor contributing to the growth of agricultural production is the expansion of irrigated agriculture, which facilitates increased crop production on land already in production. The amount of irrigated land continues to grow at a much faster rate than the expansion of all agricultural land (Fig. 3). Land under irrigation has expanded in both developed and developing countries, including those that have shown no change or a decline in total agricultural land under production (compare Figs. 1 and 4).

The San Joaquin Valley of California is an example of a highly engineered landscape where the natural ecosystem

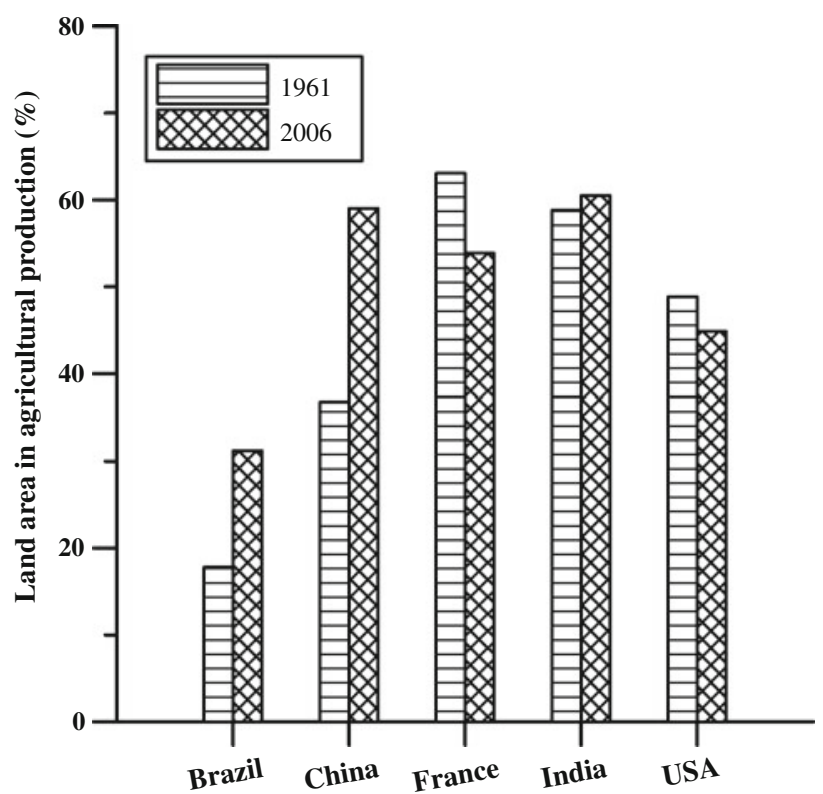

Fig. 1 Change in the amount of land area used for agricultural between 1961 and 2008 for select countries with strong agricultural economies. (Data source: United Nations Environmental Programs, 2010)

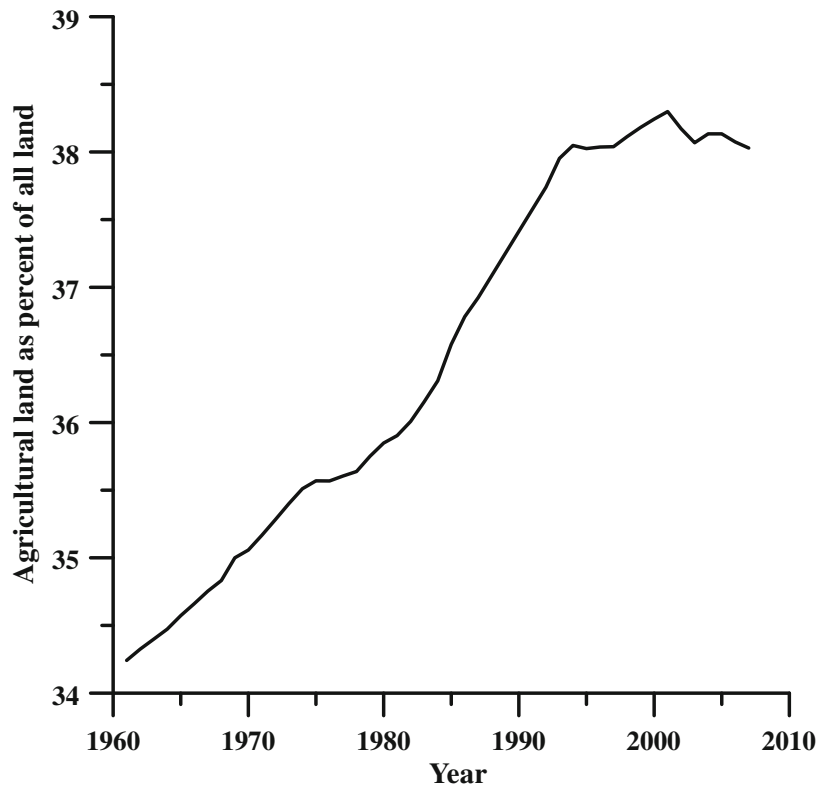

Fig. 2 Worldwide change in the amount of land area used for agricultural between 1961 and 2008. Calculated as a percent of all land, excluding polar regions. (Data source: United Nations Environmental Programs, 2010)

has been completely transformed. The hydrologic cycle of the valley is now predominately artificial (Fig. 5), and the region's wetlands have been converted wholesale to irrigated agricultural land. The San Joaquin Valley is engineered to be the most productive agricultural region in the world, despite an average total rainfall of less than $1.3 \mathrm{~cm}$ 


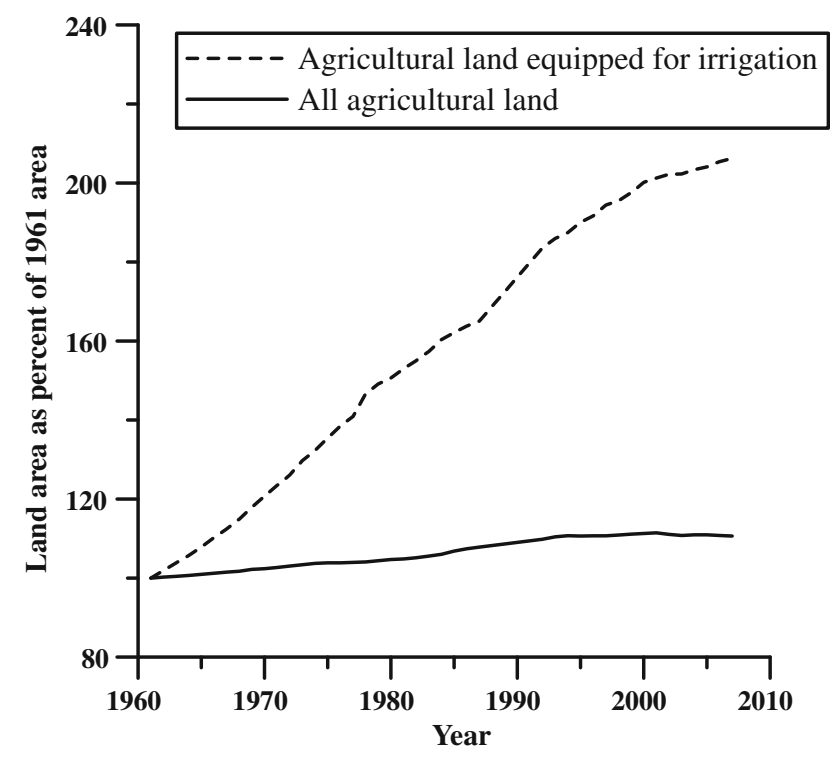

Fig. 3 Global growth in agricultural land equipped for irrigation compared to global growth in all agricultural land, expressed as a percent of land under same use in 1961. (Data source: United Nations Environmental Programs, 2010)

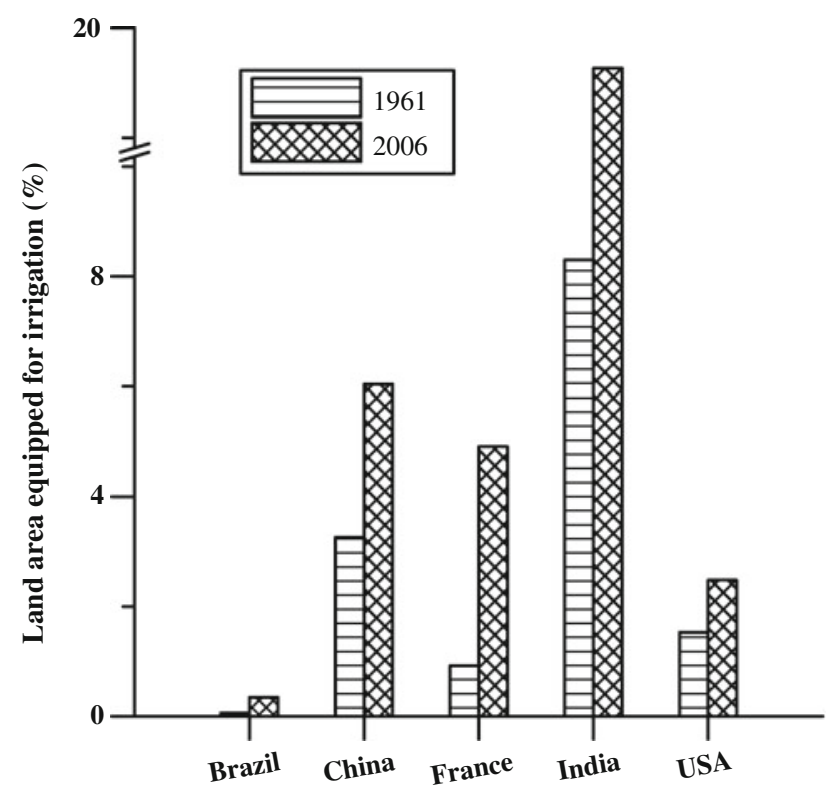

Fig. 4 Land area equipped for irrigation as a percent of all land area for selected countries with strong agricultural economies. Note broken scale on y-axis. (Data source: United Nations Environmental Programs, 2010)

during the major growing season (June-September). However, the transformation of the San Joaquin Valley has resulted in numerous environmental problems related to the loss of wetland provided ecosystem services, including excess nutrient exports to surface waters, eutrophication, and low oxygen areas in the San Joaquin River estuary, as well as numerous other surface water, ground water, and air pollution problems (Lin et al. 2002; Hall and Anderson 2003; Jassby and Nieuwenhuyse 2005; Stringfellow 2008; Stringfellow et al. 2009).

Engineering projects (including dams, canals, drains, and levees) that have transformed the valley ecosystem were designed and implemented for the purpose of economic and societal benefit. During planning, design, and construction, sustainability was not considered and ecosystem services were not incorporated. There is now a costly effort to reengineer the hydrology of the San Joaquin River to restore salmon fisheries (San Joaquin River Restoration Program 2007), but there is not yet a coordinated effort to restore overall ecosystem services to the region. Focusing on the fundamental sustainability concepts and effective and sustainable approach to engineering design would include planning for ecosystem services, such as integrating engineered wetlands into the agricultural landscape to provide nitrogen processing and other ecosystem services. When ecosystem services are incorporated into the engineering design of larger projects, experience has demonstrated tangible benefits to engineered systems (Sommer et al. 2001; Schemel et al. 2004; Fleming-Singer and Horne 2006; Maynard et al. 2009; Miller and Fujii 2010; Stringfellow et al. 2010).

\section{Engineering the global ecosystem}

Large- and small-scale hydro-engineering projects have accumulated a global impact. The total water storage design capacity for dams has increased rapidly between 1945 and 1994 (Fig. 6), and the modification of the hydrologic cycle is truly a worldwide phenomenon (Fig. 7). Many dams were constructed for water supply and flood control, with the engineering objective of a significant or complete modification of the affected watersheds natural hydrologic system; and dams for hydropower or other purposes also, obviously, eliminate natural hydrologic ecosystems. Modifying the global hydrology has provided many benefits to Earth's human inhabitants, but has not come without costs. These costs included the loss of natural ecosystem functions and their accompanying ecosystem services.

Globally, the amount of land under agricultural cultivation has increased dramatically since 1961 (Fig. 2). Watersheds worldwide have lost wetland related ecosystem functions and discharge of excess nitrogen to coastal waters (Fig. 8). Watersheds that discharge excess nitrogen and other nutrients cause a number of negative ecological impacts, including eutrophication and resulting dead zones, where low oxygen conditions predominate in large areas of coastal oceans and estuaries (Kennish 2001; Diaz and Rosenberg 2008; Halpern et al. 2008; Rabalais et al. 2009). 
(a)

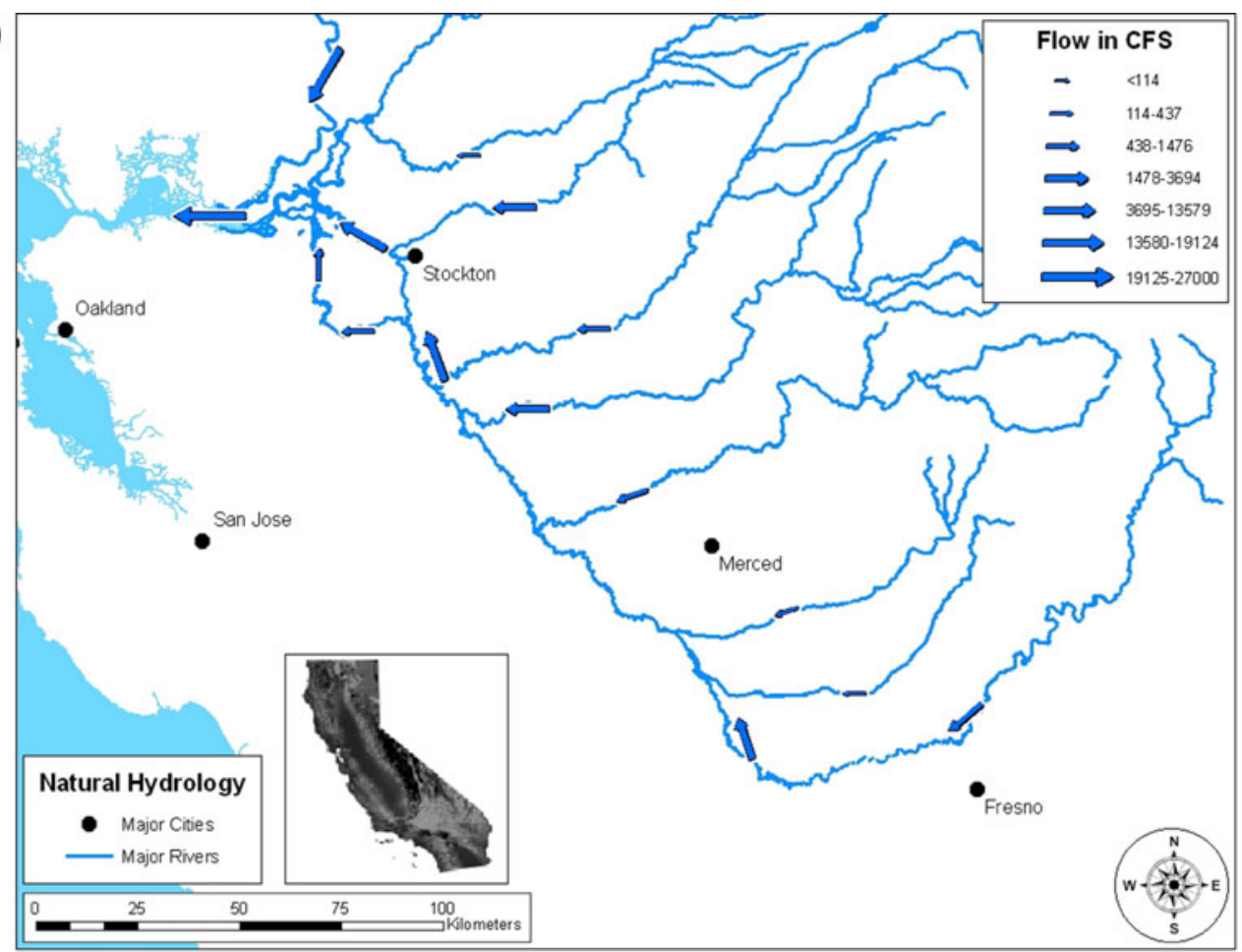

(b)

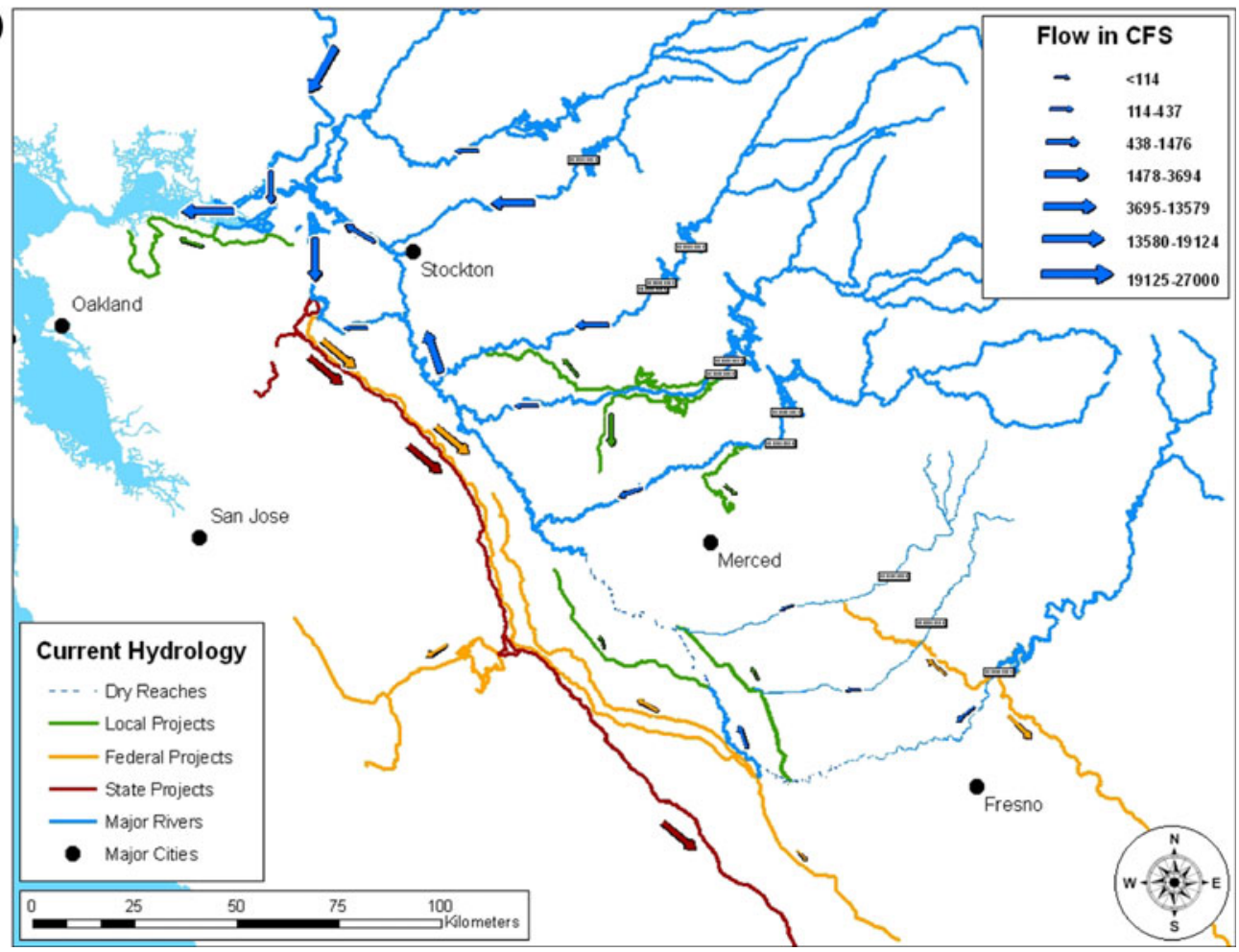

Fig. 5 a Natural hydrology of the San Joaquin River Valley, California, USA (simplified). b Current hydrology of the San Joaquin River Valley, California, USA (simplified). The hydrology of the San

As our modification of the global hydrosphere has continued, an understanding of the interrelation between the engineering of our ecosystem and negative consequences
Joaquin River Valley has been modified to provide social and economic benefits to California. Loss of ecosystem services was not considered in most engineering designs

due to loss of ecosystem services has emerged. Our modification of the Earth's hydrology is having a disproportionate and unnecessarily negative impact on ecosystem 


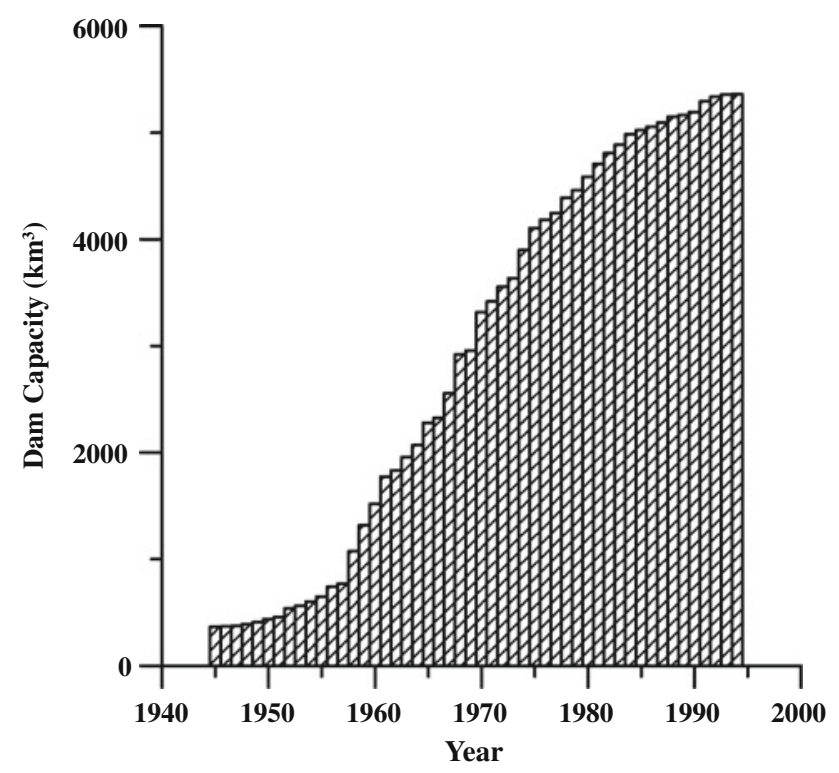

Fig. 6 Cumulative total, global dam storage capacity since the end of World War II. (Data source: United Nations Environmental Programs, 2010) function, because sustainability and ecosystem services are not considered in the design of large water projects.

\section{Engineering a sustainable global ecosystem}

Retrofitting a system is typically more expensive and less effective than providing initial proper engineering design. Globally, there are several large-scale hydrologic projects currently under design or implementation, including the North-South Diversion Project in China, the Irtysh-Karaganda canal project in Kazakhstan, the Southeastern Anatolia Project in Turkey, and the Himalayan and Peninsular Rivers projects in India (Roul 2009; Industry Projects 2010). Many of these projects are on the scale of, or larger, than the water projects in the San Joaquin Valley, California, and will transform the ecosystem of large regions of the planet. Although some projects may include design criteria to mitigate impacts, currently there is no attempt to include engineered ecosystems to replace the loss of the natural ecosystem function that will result from these
Fig. 7 Location of major dams (red symbols) completed by Nations Environmental Programs, 2010) 1994. (Data source: United

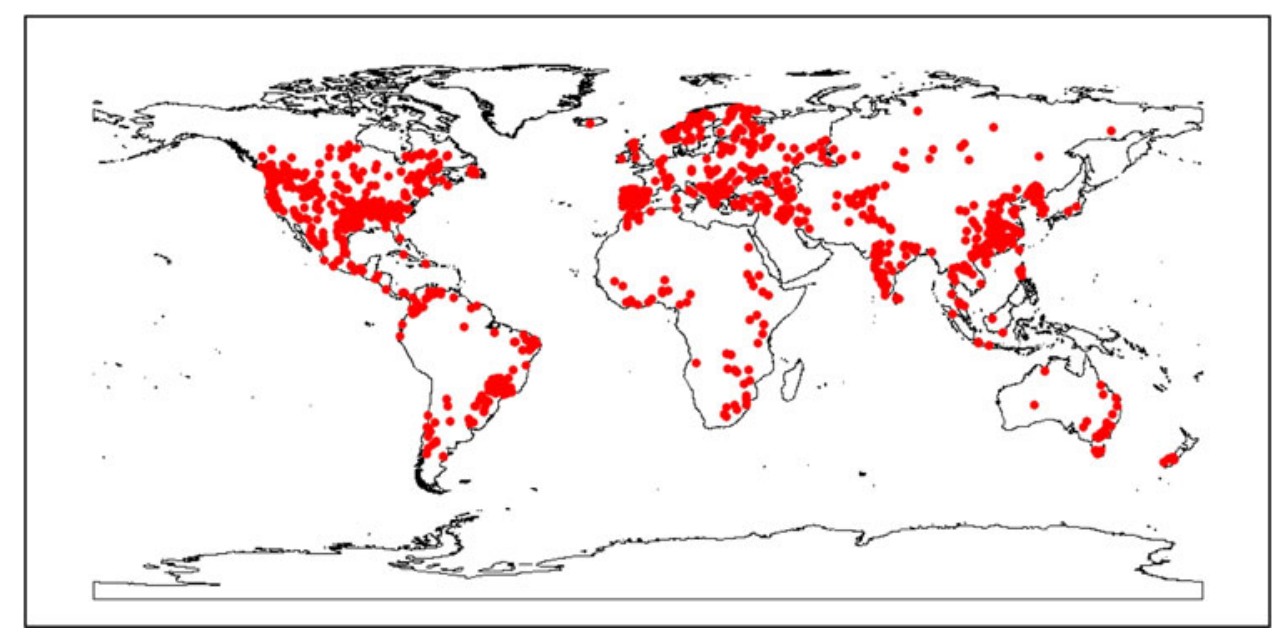

Fig. 8 Marine and major inland waters impacted by elevated rates of nitrogen flux from surrounding watersheds. Surface waters impacted by elevated nitrogen inputs are located in watersheds with significant hydrological modification and high agricultural densities. (Data source: United Nations Environmental Programs, 2010)

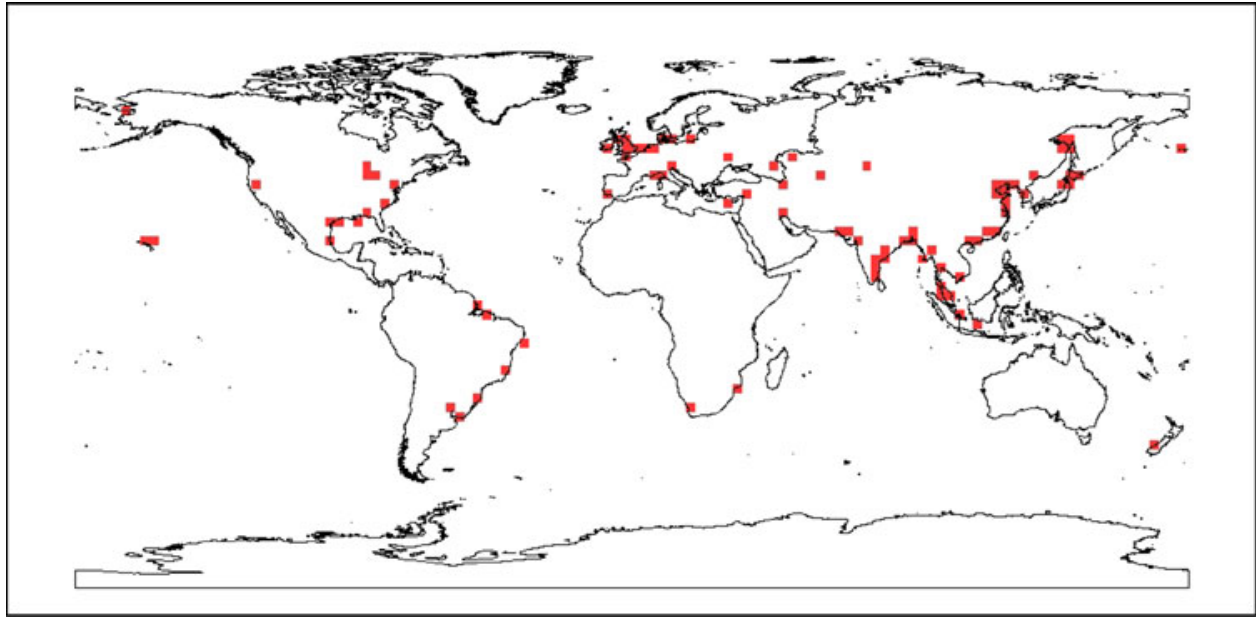


projects. Designs for new, large-scale hydrologic projects should include explicit planning for ecosystem services, such as periodic flooding of riparian areas and the incorporation of wetlands to control watershed nutrient flux rates. Incorporation of flood plains and wetlands in hydrologic design can maintain ecosystem services or functions without the loss of flood control capability or agricultural productivity (Sommer et al. 2001; Schemel et al. 2004; Stringfellow et al. 2010).

In summary, including ecosystem functions in engineering designs will come down to a matter of human will, including our willingness to include ecosystem costs in our economic analyses. Continual development of engineering criteria for the design of ecosystem functions is necessary, but many design criteria are already known; therefore, it should be expected that the design of ecosystem services be included in all modern, large-scale hydrologic projects. The management of watershed hydrology, environmental quality, and land use is compartmentalized now, but it needs to be integrated in the future, if we are to engineer sustainable systems.

The concept of sustainability requires that we meet the needs of the present without compromising the ability of future generations to meet their essential needs. We may have engineered well to respond to economic and other current societal needs, but not in terms of long-term viability and sustainability of the environment. It has always been assumed that ecosystem functions will be provided free, by "nature," and too often natural systems are considered as "set-asides" that are preserved outside of our highly engineered human habitat. What has become clear since the 1960s is that the human trajectory is not "back to nature," but we have become keepers of our own ecosystem. All of the evidence is pointing to the inevitable conclusion that reliance on set-aside areas to provide ecosystem services is not a successful strategy, rather the sustainable improvement of the human condition will require deliberate and thoughtful ecosystem engineering.

Open Access This article is distributed under the terms of the Creative Commons Attribution Noncommercial License which permits any noncommercial use, distribution, and reproduction in any medium, provided the original author(s) and source are credited.

\section{References}

Asimov I (1952) The martian way. Galaxy science fiction. Galaxy Publishing Corp., New York

Blann KL, Anderson JL, Sands GR, Vondracek B (2009) Effects of agricultural drainage on aquatic ecosystems: a review. Crit Rev Environ Sci Technol 39:909-1001
Der AT (1999) Balancing stream and wetland preservation with nonpoint source pollution management: a case study. Water Sci Technol 40:137-144

Diaz RJ, Rosenberg R (2008) Spreading dead zones and consequences for marine ecosystems. Science 321:926-929

Doyle MW, Yates AJ (2010) Stream ecosystem service markets under no-net-loss regulation. Ecol Econ 69:820-827

Fleming-Singer MS, Horne AJ (2006) Balancing wildlife needs and nitrate removal in constructed wetlands: the case of the Irvine Ranch Water District's San Joaquin Wildlife Sanctuary. Ecol Eng 26:147-166

Foote AL, Pandey S, Krogman NT (1996) Processes of wetland loss in India. Environ Conserv 23:45-54

Hall LW, Anderson RD (2003) Parametric and probabilistic analysis of historical chlorpyrifos surface water monitoring data from the San Joaquin River watershed: 1991-2001. Water Air Soil Pollut 150:275-298

Halpern BS, Walbridge S, Selkoe KA, Kappel CV, Micheli F, D’Agrosa C, Bruno JF, Casey KS, Ebert C, Fox HE, Fujita R, Heinemann D, Lenihan HS, Madin EMP, Perry MT, Selig ER, Spalding M, Steneck R, Watson R (2008) A global map of human impact on marine ecosystems. Science 319:948-952

Huang Y, Sun WJ, Zhang W, Yu YQ, Su YH, Song CC (2010) Marshland conversion to cropland in northeast China from 1950 to 2000 reduced the greenhouse effect. Global Change Biol 16:680-695

Industry Projects (2010). Water technology. Net Resources International

Jassby A, Nieuwenhuyse EEV (2005) Low dissolved oxygen in an estuarine channel (San Joaquin River, California): mechanisms and models based on long-term time series. San Francisco Estuary and Watershed Science 3 (on line journal)

Kennish MJ (2001) Coastal salt marsh systems in the US: a review of anthropogenic impacts. J Coastal Res 17:731-748

Lemly AD, Kingsford RT, Thompson JR (2000) Irrigated agriculture and wildlife conservation: conflict on a global scale. Environ Manage 25:485-512

Lin ZQ, Cervinka V, Pickering IJ, Zayed A, Terry N (2002) Managing selenium-contaminated agricultural drainage water by the integrated on-farm drainage management system: role of selenium volatilization. Water Res 36:3150-3160

Maynard JJ, O'Geen AT, Dahlgren RA (2009) Bioavailability and fate of phosphorus in constructed wetlands receiving agricultural runoff in the San Joaquin Valley, California. J Environ Qual 38:360-372

Miller RL, Fujii R (2010) Plant community, primary productivity, and environmental conditions following wetland re-establishment in the Sacramento-San Joaquin Delta, California. Wetlands Ecol Manage 18:1-16

Nicholls RJ (2004) Coastal flooding and wetland loss in the 21st century: changes under the SRES climate and socio-economic scenarios. Global Environ Change-Hum Policy Dimens 14:6986

Nicholls RJ, Hoozemans FMJ, Marchand M (1999) Increasing flood risk and wetland losses due to global sea-level rise: regional and global analyses. Global Environ Change-Hum Policy Dimens 9:S69-S87

Rabalais NN, Turner RE, Díaz RJ, Justic D (2009) Global change and eutrophication of coastal waters. ICES J Marine Sci 66:15281537

Roul A (2009). India's water future. are interbasin water transfers a solution? EcoWorld Magazine. http://www.Ecoworld.com

San Joaquin River Restoration Program (2007). Program Management Plan

Schemel LE, Sommer TR, Muller-Solger AB, Harrell WC (2004) Hydrologic variability, water chemistry, and phytoplankton 
biomass in a large floodplain of the Sacramento River, CA, USA. Hydrobiologia 513:129-139

Sommer T, Harrell B, Nobriga M, Brown R, Moyle P, Kimmerer W, Schemel L (2001) California's Yollo bypass: evidence that flood control can be compatible with fisheries, wetlands, wildlife, and agriculture. Fisheries 26:6-16

Stringfellow WT (2008) Ranking tributaries for setting remediation priorities in a TMDL context. Chemosphere 71:1895-1908

Stringfellow W, Herr J, Litton G, Brunell M, Borglin S, Hanlon J, Chen C, Graham J, Burks R, Dahlgren R, Kendall C, Brown R, Quinn N (2009) Investigation of river eutrophication as part of a low dissolved oxygen total maximum daily load implementation. Water Sci Technol 59:9-14

Stringfellow W, Graham J, Rogers M, Borglin S, Brunell M, Hanlon J, Spier C, Nguyen K (2010) Water quality changes occurring in agricultural drains of varying riparian function. In: Moore MT, Kröger R (eds) Agricultural drainage ditches: mitigation wetlands for the 21st Century. Research Signpost, Kerala, India, pp 173-194
United Nations (2008) Trends in sustainable development. United Nations Publications, New York, NY

United Nations Development Programs (2009) Human development report 2009: overcoming barriers: human mobility and development. Palgrave Macmillan Houndmills, New York, NY

United Nations Environmental Programs (2010). Global environmental outlook data portal. United Nations environment programme global environment outlook. http://geodata.grid.unep.ch/. Accessed 16 Mar 2010

United States Census Bureau (2010) International Data Base

Wamsley TV, Cialone MA, Smith JM, Atkinson JH, Rosati JD (2010) The potential of wetlands in reducing storm surge. Ocean Eng 37:59-68

Zedler JB, Callaway JC (2000) Evaluating the progress of engineered tidal wetlands. Ecol Eng 15:211-225

Zedler JB, Kercher S (2005) Wetland resources: status, trends, ecosystem services, and restorability. Ann Rev Environ Res 30:39-74 